\title{
Article \\ The Comprehensive Effects of Rhizophagus intraradices and $P$ on Root System Architecture and P Transportation in Citrus limon L.
}

\author{
Chun-Yan Liu ${ }^{1,2} \mathbb{D}$, Xiao-Niu Guo ${ }^{1,2}$, Xiao-Long Wu ${ }^{1,2}$, Feng-Jun Dai ${ }^{1,2}$ and Qiang-Sheng $\mathrm{Wu}^{1,2, * \mathbb{C}}$ \\ 1 College of Horticulture and Gardening, Yangtze University, Jingzhou 434025, China; \\ 201573031@yangtzeu.edu.cn (C.-Y.L.); 201807759@yangtzeu.edu.cn (X.-N.G.); \\ 201807771@yangtzeu.edu.cn (X.-L.W.); 202072835@yangtzeu.edu.cn (F.-J.D.) \\ 2 Institute of Root Biology, Yangtze University, Jingzhou 434025, China \\ * Correspondence: wuqiangsheng@yangtzeu.edu.cn
}

Citation: Liu, C.-Y.; Guo, X.-N.; Wu, X.-L.; Dai, F.-J.; Wu, Q.-S. The Comprehensive Effects of Rhizophagus intraradices and $\mathrm{P}$ on Root System Architecture and P Transportation in Citrus limon L. Agriculture 2022, 12, 317. https:// doi.org/10.3390/agriculture12030317

Academic Editor: Nadia Massa

Received: 17 January 2022

Accepted: 21 February 2022

Published: 22 February 2022

Publisher's Note: MDPI stays neutral with regard to jurisdictional claims in published maps and institutional affiliations.

Copyright: (C) 2022 by the authors. Licensee MDPI, Basel, Switzerland. This article is an open access article distributed under the terms and conditions of the Creative Commons Attribution (CC BY) license (https:// creativecommons.org/licenses/by/ $4.0 /)$.

\begin{abstract}
Both arbuscular mycorrhizal fungi (AMF) and phosphorus (P) collectively influence the root system architecture (RSA), but whether the combination of the two affects RSA, particularly lateral root formation, is unknown. In the present study, a pot experiment was conducted to evaluate the effects of an arbuscular mycorrhizal fungus (Rhizophagus intraradices) on the RSA of lemon (Citrus limon L.) seedlings under $0\left(\mathrm{P}_{0}\right)$ and $50 \mathrm{mg} / \mathrm{kg}\left(\mathrm{P}_{50}\right) \mathrm{P}$ levels. Moreover, $\mathrm{P}$ and carbohydrate content; acid phosphatase activity; and the expression of $\mathrm{P}$ transporter genes (PTs), phosphatase genes (PAPs), and lateral-root-related genes; were determined. Our results show that root mycorrhizal colonization and mycorrhizal dependency of lemon plants are significantly higher under $\mathrm{P}_{0}$ than under $\mathrm{P}_{50}$ conditions. AMF significantly promoted the plant growth performance of lemon, irrespective of substrate P levels. The RSA parameters of AMF plants, including total root length, projected area, surface area, average diameter, volume, and second- and third-order lateral root numbers, were distinctly increased under the two P levels compared to those of non-AMF plants. Mycorrhizal treatment also induced higher carbohydrate (sucrose, glucose, and fructose) and P contents, along with a higher activity of root acid phosphatase. The expression of P-related genes, including ClPAP1, ClPT1, ClPT3, ClPT5, and ClPT7, as well as the expression of lateral-root-related genes (ClKRP6, ClPSK6, and ClRSI-1), was dramatically upregulated by AMF inoculation, irrespective of substrate $\mathrm{P}$ levels. Principal component analysis showed that root $\mathrm{P}$ and carbohydrate contents, as well as the expression of ClKRP6 and ClPSK6, were positively correlated with RSA traits and lateral root development. Our study demonstrates that mycorrhizas accelerate the P acquisition and carbohydrate accumulation of lemon plants by upregulating the expression of lateral-root-related genes, thereby positively improving the RSA. Furthermore, AMF had a greater impact on the RSA of lemon than substrate P levels.
\end{abstract}

Keywords: citrus; mycorrhiza; lateral roots; phosphorus; root system

\section{Introduction}

Root systems are the primary part of a plant; they perceive changes in the soil environment and are also the major absorptive organ responsible for supporting shoot growth and development, as they acquire mineral nutrients and water from the soil [1]. Roots are important for plants, providing access to available resources, as evidenced by their accelerated growth and increased length in nutrient-rich areas, as well as by the spatial distribution of the length, root angle, and branching of the well-constructed root system architecture (RSA) [2]. In response to environmental stress, RSA can be modified to enhance the capacity of plant nutrient acquisition [3].

Phosphorus $(\mathrm{P})$ participates in various metabolic pathways of plants and is a key component of nucleic acids, adenosine triphosphate, and phospholipids [4]. Due to its 
immobility in soil, its low availability frequently limits the growth of crops throughout the world [5,6], especially in Oxisols and saline-alkali soils [7]. Root morphological adaptations, physiological changes that include organic compound exudation, and microbial cooperation are major strategies used by plants to overcome P limitation [8]. However, the concentration, availability, and distribution of $\mathrm{P}$ directly affect root morphogenesis. A previous study reported that treatments with different $P$ levels $(0,0.1$, and $10 \mathrm{mM})$ significantly inhibited root development by decreasing the values of root morphological traits (total length, surface area, projected area, volume, taproot length, and number of lateral roots) in trifoliate orange seedlings [9]. Another study showed that 5 and $10 \mathrm{mg} / \mathrm{kg}$ P fertilization supplement dramatically decreased the root length but increased the root volume of cucumber seedlings [10]. Studies have shown that root morphology is strongly reduced under low- and high-P treatments, which may be related to the lower transportation of carbohydrates into root systems [9]. However, the addition of $\mathrm{P}$ at low concentrations has been observed to stimulate the root growth and development of tobacco, dependent on plant genotypes and substrate P levels [11].

In addition to P, rhizosphere microorganisms also affect RSA, especially arbuscular mycorrhizal fungi (AMF). AMF are beneficial microorganisms that can establish symbiotic relationships with the roots of most terrestrial plants [12]. The establishment of root architecture is extremely important for plant development and is reflected in many plant traits, including root biomass, length, volume, angle, lateral root occurrence, adventitious root formation, and root hair growth [13,14]. The effect of AMF on these RSA parameters has been confirmed in various plant species [12,15]. Root architecture can be promoted by AMF, which is associated with improved nutrients, especially P [16]. Extensive extraradical hyphae not only improve plant $\mathrm{P}$ absorption but also improve $\mathrm{P}$ transfer efficiency [17]. Furthermore, several genes proposed to be related to RSA have recently attracted great attention. In Arabidopsis, ARFs regulate lateral root formation via the direct activation of $L B D / A S L s$ [18], and the expression of KRP1 leads to a decrease in the number of lateral roots [19]. Furthermore, rum 1 inhibited root development in maize by reducing the polar transport of auxin in its roots [20]. In trifoliate orange seedlings, lateral root development was affected by the expression of KPR6, RSI-1, NAC2, and PSK6, and the development of lateral roots had a significant positive correlation with the expression of PSK6 [1]. However, whether these candidate genes involved in root construction are regulated by mycorrhizal colonization remains unanswered.

Although the effect of AMF on RSA development has been studied [1,12], little information is known about the underlying mechanism. Our previous studies showed that AMF and $\mathrm{P}$ improve the architecture of citrus roots to varying degrees [9,21], although it is not clear which of the two plays a dominant role in RSA. As a result, a pot experiment was conducted to screen out the main factor affecting RSA establishment and underlying the interaction between AMF and P (at two concentrations) and its effect on the RSA of lemon (Citrus limon L.) seedlings inoculated with Rhizophagus intraradices. Root morphology; root P content; phosphatase activity; carbohydrate content; and the relative expression of genes related to $\mathrm{P}$, phosphatase, and lateral root formation were determined.

\section{Materials and Methods}

\subsection{Plant Culture}

Lemon and Rhizophagus intraradices (N.C. Schenck \& G.S.Sm.) Schüßler \& Walker (BGC JX04B) were used as the host plant and AM fungus, respectively. Strain selection was based on the results of $\mathrm{Wu}$ et al. [22] on citrus seedlings. Disinfection and germination of lemon seeds were performed according to the method of Liu et al. [23] under autoclaved $\left(121^{\circ} \mathrm{C}, 0.11 \mathrm{MPa}, 2 \mathrm{~h}\right)$ sands at $25^{\circ} \mathrm{C}$ in darkness. After two weeks, two-leaf-old seedlings with $2 \mathrm{~cm}$ height were transplanted into a $2 \mathrm{~L}$ plastic pot filled with $1.5 \mathrm{~kg}$ of an autoclaved $\left(121{ }^{\circ} \mathrm{C}, 0.11 \mathrm{MPa}\right)$ mixture of soil and river sand $(2: 1 \mathrm{v} / \mathrm{v})$, along with one seedling per pot. The soils were collected from the citrus orchard of Yangtze University, and river sands were collected from the Yangtze River. The chemical properties of the mixture were as 
follows: $\mathrm{pH}$ 5.8, available nitrogen $101.8 \mathrm{mg} / \mathrm{kg}$, available $\mathrm{P} 22.38 \mathrm{mg} / \mathrm{kg}$, and available $\mathrm{K}$ $94.48 \mathrm{mg} / \mathrm{kg}$. Based on the above conditions, the present study determined whether to add additional $\mathrm{KH}_{2} \mathrm{PO}_{4}$ as $\mathrm{P}$ treatment, including 0 (deficit $\mathrm{P}: \mathrm{P}_{0}$ ) or $50 \mathrm{mg} / \mathrm{kg} \mathrm{P}$ (appropriate $\left.P: P_{50}\right)$ according to the work of Chen et al. [1].

The fungal strain was supplied by the Bank of Glomeromycota in China (BGC) and multiplied using white clover (Trifolium repense L.) for three months under greenhouse conditions. After harvesting, the AM fungal spores were identified and quantified, and approximately 30 spores per gram of inoculum were obtained. For the AMF treatment, $80 \mathrm{~g}$ (approximately 2400 spores) of the fungal strain was inoculated into each pot during lemon seedling transplantation. The inoculum amount was followed based on the number and vitality of spores. Meanwhile, the same amount of sterilized inoculum was added to the non-AMF treatment, along with $3 \mathrm{~mL}$ filtrate $(25 \mu \mathrm{m}$ filter) of mycorrhizal inoculum to ensure the consistency of microbial diversity. All the AMF and non-AMF seedlings were grown in a greenhouse under the following conditions: photosynthetic photon flux density $982 \mu \mathrm{mol} / \mathrm{m}^{2} / \mathrm{s}$, temperature $22-30{ }^{\circ} \mathrm{C}$, and relative humidity $60-80 \%$. The pots were replaced weekly until harvest after 12 weeks of transplantation.

\subsection{Experimental Design}

A completely randomized design with two factors was used. The two factors included inoculation with or without $R$. intraradices and two substrate $\mathrm{P}$ levels $\left(\mathrm{P}_{0}, \mathrm{P}\right.$ deficiency; $\mathrm{P}_{50}$, appropriate $\mathrm{P}$ ). Thus, the experiment consisted of four treatments: $\mathrm{P}$ deficit and non- $R$. intraradices inoculation $\left(\mathrm{P}_{0}-\mathrm{Ri}\right), \mathrm{P}$ deficit and $R$. intraradices inoculation $\left(\mathrm{P}_{0}+\mathrm{Ri}\right)$, appropriate $\mathrm{P}$ and non- $R$. intraradices inoculation $\left(\mathrm{P}_{50}-\mathrm{Ri}\right)$, and appropriate $\mathrm{P}$ and $R$. intraradices inoculation $\left(\mathrm{P}_{50}+\mathrm{Ri}\right)$. Each treatment comprised six replicates.

\subsection{Determination of Physiological Parameters}

All seedlings were harvested after 12 weeks of $P$ treatment. The fresh weight of shoots and roots was measured immediately. Then, the complete root systems were carefully washed and scanned using the Epson Perfection V700 Photo Dual Lens System (Seiko Epson Corp., Nagano, Japan). Root characteristics, including total root length, projected area, surface area, average diameter, and volume, were analyzed using WinRHIZO software (Regent Instruments Inc., Quebec, Canada). Then, taproot length and the number of lateral roots (LRs) were determined artificially on a test bed. The roots were then cut into approximately $1 \mathrm{~cm}$-long segments for subsequent analysis.

One hundred root segments were randomly selected to determine root mycorrhizal infection after being stained with $0.05 \%$ trypan blue [24]. Mycorrhizal dependency was calculated according to the method of Liu et al. [11].

Root $\mathrm{P}$ concentration was determined using inductively coupled plasma atomic emission spectrometry (ICP-AES, IRIS Advantage, Thermo Electron Corp., Waltham, MA, USA). Acid phosphatase activity in leaves and roots was determined by the p-nitrophenyl phosphate substrate method [25].

The concentrations of carbohydrate forms, including fructose, glucose, and sucrose, in roots were assayed according to the method of $\mathrm{Wu}$ et al. [21].

\section{4. $q R T-P C R$ for LR and Phosphatase Genes}

qRT-PCR was performed to detect the expression of LR-related genes, $\mathrm{P}$ transporter genes, and phosphatase genes. According to the manufacturer's instructions, TaKaRa MiniBEST Plant RNA Extraction Kit (9769, Takara Bio. Inc., Kusatsu, Japan) was used to extract total RNA from $0.2 \mathrm{~g}$ root fresh samples, and total RNA was reversely transcribed into cDNA and was carried out using the PrimeScriptTM RT reagent kit with gDNA eraser (PK02006, Takara Bio. Inc., Kusatsu, Japan). The expression of LR-related genes (ClPSK6, ClKRP6, and ClRSI-1), P transporter genes (ClPT1, ClPT2, ClPT3, ClPT5, and ClPT7), and phosphatase genes (ClPAP1, ClPAP2, and ClPAP3) in roots was quantified using the 185 rRNA gene as an internal reference [26]. Primer Premier 5.0 software (Palo Alto, CA, 
USA) was used to design the specific primers for above related genes, and specificity was determined using the BLAST tool of NCBI. All primers were synthesized by Shanghai Sangon (China) BioTech Co., as shown in Table 1. The volume of each reaction mixture used for qRT-PCR was $20 \mu \mathrm{L}$, which included $7.2 \mu \mathrm{L}$ ddH $_{2} \mathrm{O}, 2 \mu \mathrm{L}$ cDNA, $10 \mu \mathrm{L}$ AceQ qPCR SYBR Green Master Mix, $0.4 \mu \mathrm{L}$ forward primer, and $0.4 \mu \mathrm{L}$ reverse primer. qRT-PCR was run on a CFX96 real-time PCR Detection System (BIO-RAD, California, USA) under the following conditions: $95^{\circ} \mathrm{C}$ for $5 \mathrm{~min}, 40$ cycles of $95^{\circ} \mathrm{C}$ for $10 \mathrm{~s}, 60^{\circ} \mathrm{C}$ for $30 \mathrm{~s}$, and $72{ }^{\circ} \mathrm{C}$ for $30 \mathrm{~s}$. Each gene amplification was repeated three times with independent biological samples and each sample set with three technical replications, and the mean values were used for data analysis. The relative expression of each target gene was calculated using the $2^{-\Delta \Delta \mathrm{Ct}}$ method [27].

Table 1. Specific primer sequences of qRT-PCR.

\begin{tabular}{|c|c|c|c|}
\hline Gene & Accession Number & Sequence of Forward Primer $\left(5^{\prime} \rightarrow 3^{\prime}\right)$ & Sequence of Reverse Primer $\left(5^{\prime} \rightarrow 3^{\prime}\right)$ \\
\hline Cl18SrRNA & FJ356261.1 & TCGGGTGTTTTCACGTCTCA & CGAAGGGTCGCCGTAGGT \\
\hline ClRSI-1 & Cs6g17190 & GCTCCGGTCATCAGGTAATT & CCGAACACCGATAAGAACA \\
\hline ClPSK6 & Cs1g21390.1 & GTGCTTTTCTCСTCСTCATC & CAGGCTCATAGCTGAAACATG \\
\hline ClKRP6 & Cs1g14980.2 & AGGATCAGACCTCAATGGACAA & CAAACGGAGGACTTACTTCTCA \\
\hline CIPAP1 & JQ666163 & GATTTAGTCGTGGCTGGTCAT & GATAGACTGGAGCAGAAGGGT \\
\hline CIPAP2 & JQ666164 & GTGGTGGCTGAGGGAAGA & TCGGCAAAGATGAAGTCG \\
\hline CIPAP3 & JQ666165 & TACAACCTCAACAGTCAGTCACA & ССТТССССААТААТСССААС \\
\hline ClPT1 & JQ666156 & GCTGCTCTTACTTACTACTGGC & TGCTACCTTGTCCTCCTGA \\
\hline ClPT2 & JQ666157 & TAATGGTGTAGCGTTCTGTGG & ATAGTGGCGGAAAGTGGGTAG \\
\hline ClPT3 & JQ666158 & ACTCTGTTTCTTTCGCTTCTG & TCTTCTTGTTGGCATACTCG \\
\hline ClPT5 & JQ666160 & GGGGTTCCTCTGCTCTTT & ATGCTTTCCGTTGGTTGC \\
\hline ClPT7 & JQ666162 & AACCACAACTCGGGACAA & GAAAGCAGCAGGAATAGA \\
\hline
\end{tabular}

\subsection{Statistical Analysis}

Data (means $\pm \mathrm{SD}, n=6$ ) were analyzed by two-way analysis of variance (ANOVA) using SAS software $\mathrm{v} 8.1$, and the significant difference between treatments was compared using Duncan's multiple range tests at $p<0.05$. Principal component analysis (PCA) was performed using Origin software (Origin Pro, 2018, SR1, 64 Bit).

\section{Results}

\subsection{Changes in Mycorrhizal Development and Plant Growth Performance}

Mycorrhizal colonization was not observed in the roots of non-AMF-inoculated seedlings. In AMF-inoculated seedlings, root AM fungal colonization ranged from $24 \%$ to $39 \%$ (Figure 1). Furthermore, $\mathrm{P}$ deficiency $\left(\mathrm{P}_{0}\right)$ significantly stimulated mycorrhizal colonization by $60.93 \%$ (Table 2 ).

Table 2. Effects of Rhizophagus intraradices on root AMF colonization and growth performance of lemon (Citrus limon L.) seedlings grown in $0 \mathrm{mg} / \mathrm{kg}\left(\mathrm{P}_{0}\right)$ and $50 \mathrm{mg} / \mathrm{kg}\left(\mathrm{P}_{50}\right) \mathrm{P}$ levels.

\begin{tabular}{|c|c|c|c|c|c|c|c|}
\hline \multirow{2}{*}{ Treatment } & \multirow{2}{*}{$\begin{array}{c}\text { Root AMF } \\
\text { Colonization (\%) }\end{array}$} & \multirow{2}{*}{$\begin{array}{c}\text { Mycorrhizal } \\
\text { Dependence (\%) }\end{array}$} & \multirow{2}{*}{$\begin{array}{l}\text { Plant Height } \\
\text { (cm) }\end{array}$} & \multirow{2}{*}{$\begin{array}{c}\text { Leaf } \\
\text { Number }\end{array}$} & \multicolumn{3}{|c|}{ Biomass (g FW/Plant) } \\
\hline & & & & & Leaf & Stem & Root \\
\hline $\mathrm{P}_{0}-\mathrm{Ri}$ & $0.00 \pm 0.00 \mathrm{c}$ & $0.00 \pm 0.00 \mathrm{c}$ & $8.18 \pm 0.84 b$ & $8 \pm 1 b$ & $0.27 \pm 0.02 c$ & $0.26 \pm 0.02 b$ & $0.53 \pm 0.04 c$ \\
\hline $\mathrm{P}_{0}+\mathrm{Ri}$ & $38.96 \pm 0.35 \mathrm{a}$ & $68.63 \pm 5.38 \mathrm{a}$ & $14.1 \pm 1.39 \mathrm{a}$ & $16 \pm 2 \mathrm{a}$ & $1.73 \pm 0.16 \mathrm{a}$ & $0.82 \pm 0.07 \mathrm{a}$ & $1.16 \pm 0.16 \mathrm{a}$ \\
\hline $\mathrm{P}_{50}-\mathrm{Ri}$ & $0.00 \pm 0.00 c$ & $0.00 \pm 0.00 c$ & $8.48 \pm 0.58 b$ & $7 \pm 1 b$ & $0.27 \pm 0.02 c$ & $0.26 \pm 0.03 b$ & $0.75 \pm 0.06 b$ \\
\hline $\mathrm{P}_{50}+\mathrm{Ri}$ & $24.21 \pm 0.24 b$ & $49.10 \pm 5.01 \mathrm{~b}$ & $\begin{array}{r}14.22 \pm 0.59 \mathrm{a} \\
\text { Significa }\end{array}$ & $15 \pm 1 \mathrm{a}$ & $0.79 \pm 0.04 \mathrm{~b}$ & $0.79 \pm 0.08 \mathrm{a}$ & $1.09 \pm 0.11 \mathrm{a}$ \\
\hline $\mathrm{Ri}$ & 0.0082 & 0.0079 & $<0.0001$ & $<0.0001$ & $<0.0001$ & 0.4637 & 0.0411 \\
\hline $\mathrm{P}$ & $<0.0001$ & $<0.0001$ & 0.5136 & 0.0407 & $<0.0001$ & $<0.0001$ & 0.0001 \\
\hline $\mathrm{Ri} \times \mathrm{P}$ & 0.0082 & 0.0079 & 0.0358 & 0.0307 & $<0.0001$ & 0.5669 & 0.0438 \\
\hline
\end{tabular}

Different small letters indicate significant difference within the same column at 0.05 level by LSD. Abbreviation: Ri: Rhizophagus intraradices; $\mathrm{P}_{0}: 0 \mathrm{mg} / \mathrm{kg} ; \mathrm{P}_{50}: 50 \mathrm{mg} / \mathrm{kg}$. 


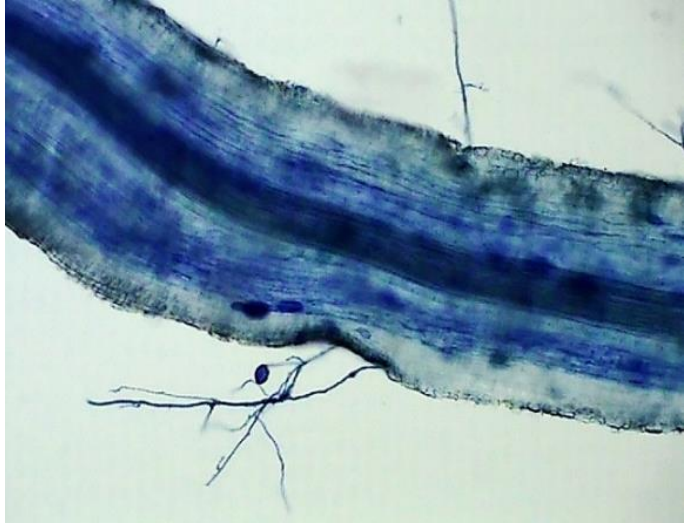

(a)

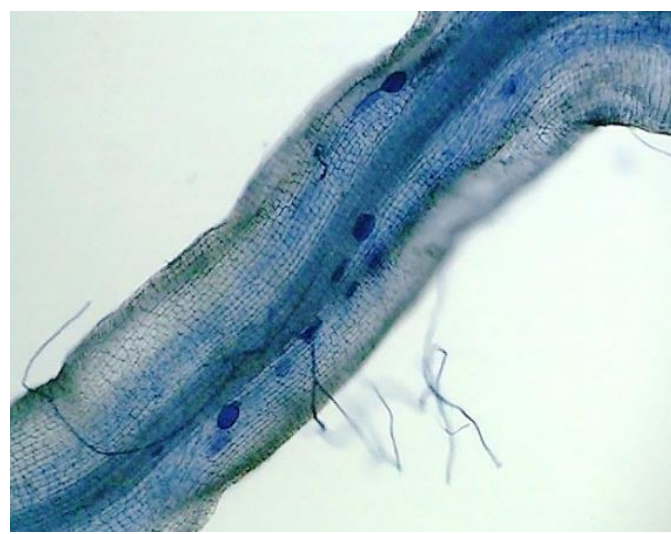

(b)

Figure 1. Mycorrhizal development of lemon (Citrus limon L.) seedlings colonized by Rhizophagus intraradices under $\mathrm{P}_{0}(\mathbf{a})$ and $\mathrm{P}_{50}(\mathbf{b})$ treatment. Abbreviation: $\mathrm{P}_{0}: 0 \mathrm{mg} / \mathrm{kg} ; \mathrm{P}_{50}: 50 \mathrm{mg} / \mathrm{kg}$.

Compared with $\mathrm{P}_{50}$ treatment, $\mathrm{P}_{0}$ treatment significantly decreased root biomass by $29.33 \%$ in non-AMF seedlings while significantly increasing leaf biomass by $118.99 \%$ in AMF-colonized seedlings (Table 2). However, plant growth performance, including height, leaf number, and biomass, was markedly increased by $R$. intraradices inoculation under both $\mathrm{P}_{0}$ and $\mathrm{P}_{50}$. Moreover, lemon seedlings under $\mathrm{P}_{0}$ treatment had a higher mycorrhizal dependency than the seedlings under $P_{50}$ treatment (Table 2).

\subsection{Changes in Root Morphology}

$\mathrm{P}_{0}$ treatment showed significantly higher total root length, projector area, volume, and third-order lateral root numbers irrespective of AMF inoculation (Table 3). Furthermore, AMF-treated seedlings presented significantly higher root traits, including total root length, project area, surface area, volume, taproot length, and number of second- and third-order lateral roots in both $\mathrm{P}_{0}$ and $\mathrm{P}_{50}$ conditions. The results also show a regulatory difference between AMF and $\mathrm{P}$ addition on RSA, and AMF exerted a greater impact on LR formation than P levels (Table 3).

Table 3. Effects of Rhizophagus intraradices on root system architecture (RSA) of lemon (Citrus limon L.) seedlings grown in $0 \mathrm{mg} / \mathrm{kg}\left(\mathrm{P}_{0}\right)$ and $50 \mathrm{mg} / \mathrm{kg}\left(\mathrm{P}_{50}\right) \mathrm{P}$ levels.

\begin{tabular}{|c|c|c|c|c|c|c|c|c|c|}
\hline \multirow{2}{*}{ Treatment } & \multirow{2}{*}{$\begin{array}{l}\text { Total Length } \\
\text { (cm) }\end{array}$} & \multirow{2}{*}{$\begin{array}{l}\text { Project Area } \\
\left(\mathrm{cm}^{2}\right)\end{array}$} & \multirow{2}{*}{$\begin{array}{l}\text { Surface Area } \\
\qquad\left(\mathrm{cm}^{2}\right)\end{array}$} & \multirow{2}{*}{$\begin{array}{c}\text { Average } \\
\text { Diameter } \\
(\mathrm{mm})\end{array}$} & \multirow{2}{*}{ Volume $\left(\mathrm{cm}^{3}\right)$} & \multirow{2}{*}{$\begin{array}{c}\text { Taproot } \\
\text { Length }(\mathrm{cm})\end{array}$} & \multicolumn{3}{|c|}{$\begin{array}{c}\text { Number of Lateral Roots } \\
\text { (Number/plant) }\end{array}$} \\
\hline & & & & & & & $\begin{array}{l}\text { 1st- } \\
\text { Order }\end{array}$ & $\begin{array}{l}\text { 2nd- } \\
\text { Order }\end{array}$ & $\begin{array}{l}\text { 3rd- } \\
\text { Order }\end{array}$ \\
\hline $\mathrm{P}_{0}-\mathrm{Ri}$ & $141.05 \pm 9.90 \mathrm{~b}$ & $10.67 \pm 0.56 b$ & $13.29 \pm 1.01 b c$ & $0.662 \pm 0.017 c$ & $0.548 \pm 0.045 c$ & $13.50 \pm 0.62 c$ & $39 \pm 3 b$ & $17 \pm 1 \mathrm{c}$ & $3 \pm 1 b$ \\
\hline $\mathrm{P}_{0}+\mathrm{Ri}$ & $202.18 \pm 6.29 a$ & $13.31 \pm 1.46 \mathrm{a}$ & $15.20 \pm 0.82 \mathrm{a}$ & $0.853 \pm 0.054 \mathrm{~b}$ & $0.862 \pm 0.068 \mathrm{a}$ & $21.33 \pm 1.59 \mathrm{a}$ & $60 \pm 4 a$ & $59 \pm 2 a$ & $14 \pm 1 \mathrm{a}$ \\
\hline $\mathrm{P}_{50}-\mathrm{Ri}$ & $118.68 \pm 6.14 \mathrm{c}$ & $9.49 \pm 0.96 c$ & $12.36 \pm 0.71 \mathrm{c}$ & $0.655 \pm 0.026 \mathrm{c}$ & $0.381 \pm 0.024 \mathrm{~d}$ & $12.27 \pm 1.25 \mathrm{c}$ & $40 \pm 3 b$ & $22 \pm 2 c$ & $0 \pm 0 \mathrm{c}$ \\
\hline $\mathrm{P}_{50}+\mathrm{Ri}$ & $147.73 \pm 10.58 b$ & $11.09 \pm 1.03 \mathrm{~b}$ & $13.35 \pm 0.59 \mathrm{~b}$ & $\begin{array}{r}0.978 \pm 0.075 \mathrm{a} \\
\text { Significance }\end{array}$ & $0.799 \pm 0.014 b$ & $17.17 \pm 0.76 \mathrm{~b}$ & $41 \pm 3 b$ & $45 \pm 3 b$ & $4 \pm 1 b$ \\
\hline $\mathrm{Ri}$ & $<0.0001$ & 0.0009 & 0.0177 & $<0.0001$ & $<0.0001$ & $<0.0001$ & 0.0004 & $<0.0001$ & $<0.0001$ \\
\hline $\mathrm{P}$ & $<0.0001$ & 0.0034 & 0.0308 & 0.0679 & 0.0017 & 0.0032 & 0.0013 & 0.0043 & $<0.0001$ \\
\hline $\mathrm{Ri} \times \mathrm{P}$ & 0.0112 & 0.2499 & 0.1977 & 0.0476 & 0.0713 & 0.0058 & 0.0007 & $<0.0001$ & 0.0016 \\
\hline
\end{tabular}

Different small letters indicate significant difference within the same column at 0.05 level by LSD. Abbreviation: Ri: Rhizophagus intraradices; $\mathrm{P}_{0}: 0 \mathrm{mg} / \mathrm{kg} ; \mathrm{P}_{50}: 50 \mathrm{mg} / \mathrm{kg}$.

\subsection{Changes in Root P Content and Phosphatase Activity}

Compared to $\mathrm{P}_{50}, \mathrm{P}_{0}$ treatment substantially decreased root $\mathrm{P}$ content by $29.01 \%$ in non-AMF seedlings but dramatically increased it by $15.42 \%$ in AMF seedlings (Figure 2a). $\mathrm{P}_{0}$ markedly stimulated root phosphatase activity by $94.74 \%$ and $24.77 \%$ in non-AMF- and AMF-colonized seedlings, respectively, compared to $P_{50}$ treatment. Furthermore, AMF colonization substantially increased root $\mathrm{P}$ content and phosphatase activity under the two $\mathrm{P}$ levels compared to non-AMF-colonized seedlings (Figure $2 \mathrm{~b}$ ). There was a significant $(p<0.05)$ interaction in root P content between P treatments and AMF treatments (Table 4). 


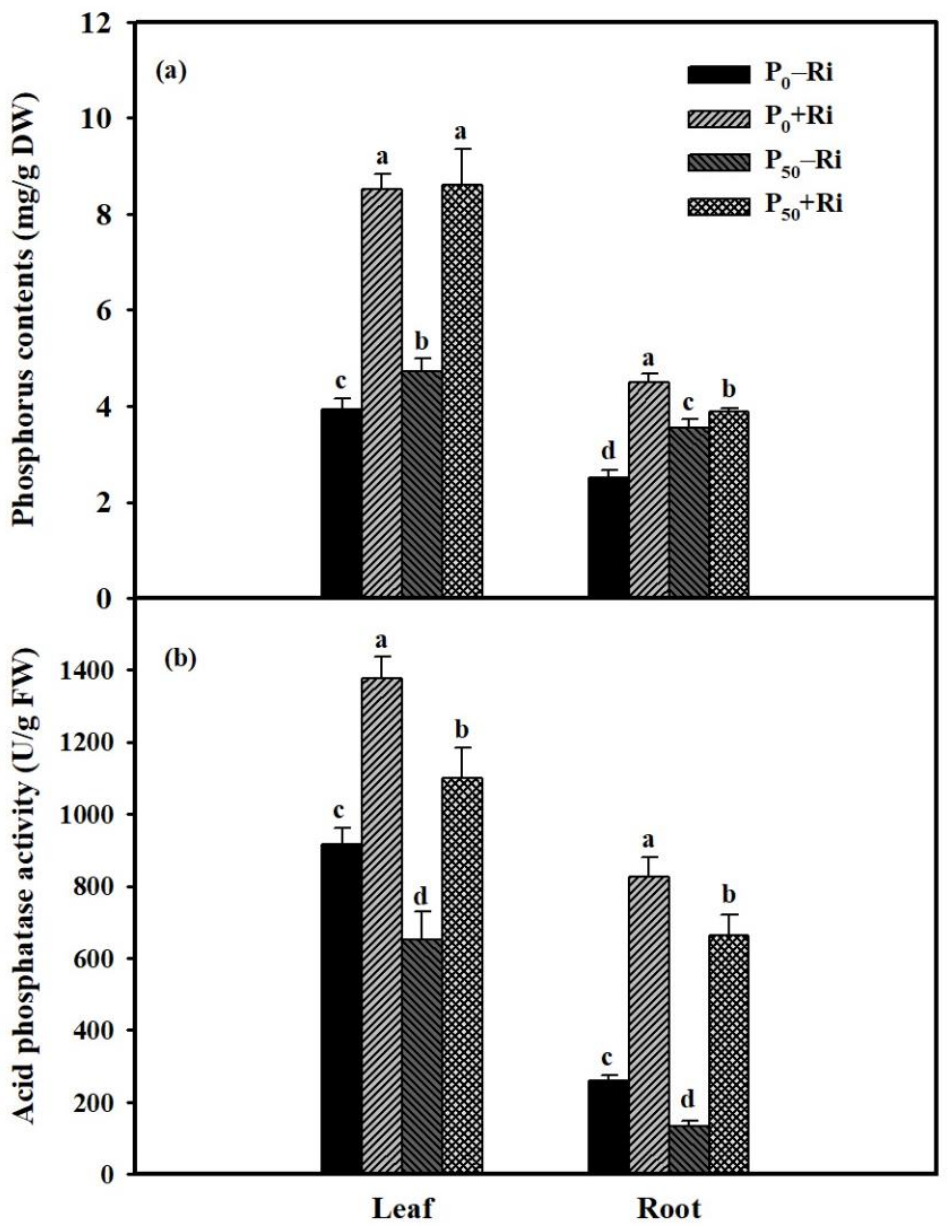

Figure 2. Effects of Rhizophagus intraradices on root $\mathrm{P}$ content (a) and acid phosphatase activity (b) of lemon (Citrus limon L.) seedlings grown in $0 \mathrm{mg} / \mathrm{kg}\left(\mathrm{P}_{0}\right)$ and $50 \mathrm{mg} / \mathrm{kg}\left(\mathrm{P}_{50}\right) \mathrm{P}$ levels. Data (means $\pm \mathrm{SD}, n=6$ ) are followed by different letters above the bars, which indicate significant differences between treatments at 0.05 level by LSD.

Table 4. Significance of variables between AMF- and non-AMF-colonized seedlings grown in $\mathrm{P}_{0}$ and $P_{50}$ P levels.

\begin{tabular}{cccc}
\hline Variation Source & $\mathbf{R i}$ & $\mathbf{P}$ & $\mathbf{R i} \times \mathbf{P}$ \\
\hline P content & $<0.0001$ & 0.0333 & $<0.0001$ \\
Phosphatase activity & 0.3334 & 0.2716 & 0.7298 \\
ClPAP1 & 0.006 & 0.0367 & 0.0507 \\
ClPAP2 & 0.4564 & 0.0103 & 0.3730 \\
ClPAP3 & 0.0150 & 0.1147 & 0.2643 \\
ClPT1 & 0.0001 & 0.0219 & 0.9495 \\
ClPT2 & 0.7931 & 0.0003 & 0.0003 \\
ClPT3 & 0.0011 & 0.1411 & 0.0373 \\
ClPT5 & $<0.0001$ & 0.2870 & 0.6459 \\
ClPT7 & 0.0004 & 0.2712 & 0.2846 \\
ClPSK6 & 0.7902 & 0.0317 & 0.1747 \\
ClKRP6 & 0.7981 & 0.0329 & 0.2313 \\
ClRSI-1 & 0.0704 & 0.1922 & 0.0037 \\
\hline
\end{tabular}




\subsection{Changes in Root Carbohydrate Concentrations}

Compared with $\mathrm{P}_{50}, \mathrm{P}_{0}$ markedly increased root fructose and glucose content, while it dramatically decreased root sucrose content, regardless of AMF inoculation (Figure 3). In contrast, mycorrhizal colonization increased root fructose, sucrose, and glucose by $27.31 \%$, $60.93 \%$, and $53.06 \%$, respectively, under $\mathrm{P}_{0}$, and by $24.13 \%, 12.39 \%$, and $45.16 \%$, respectively, under $\mathrm{P}_{50}$.

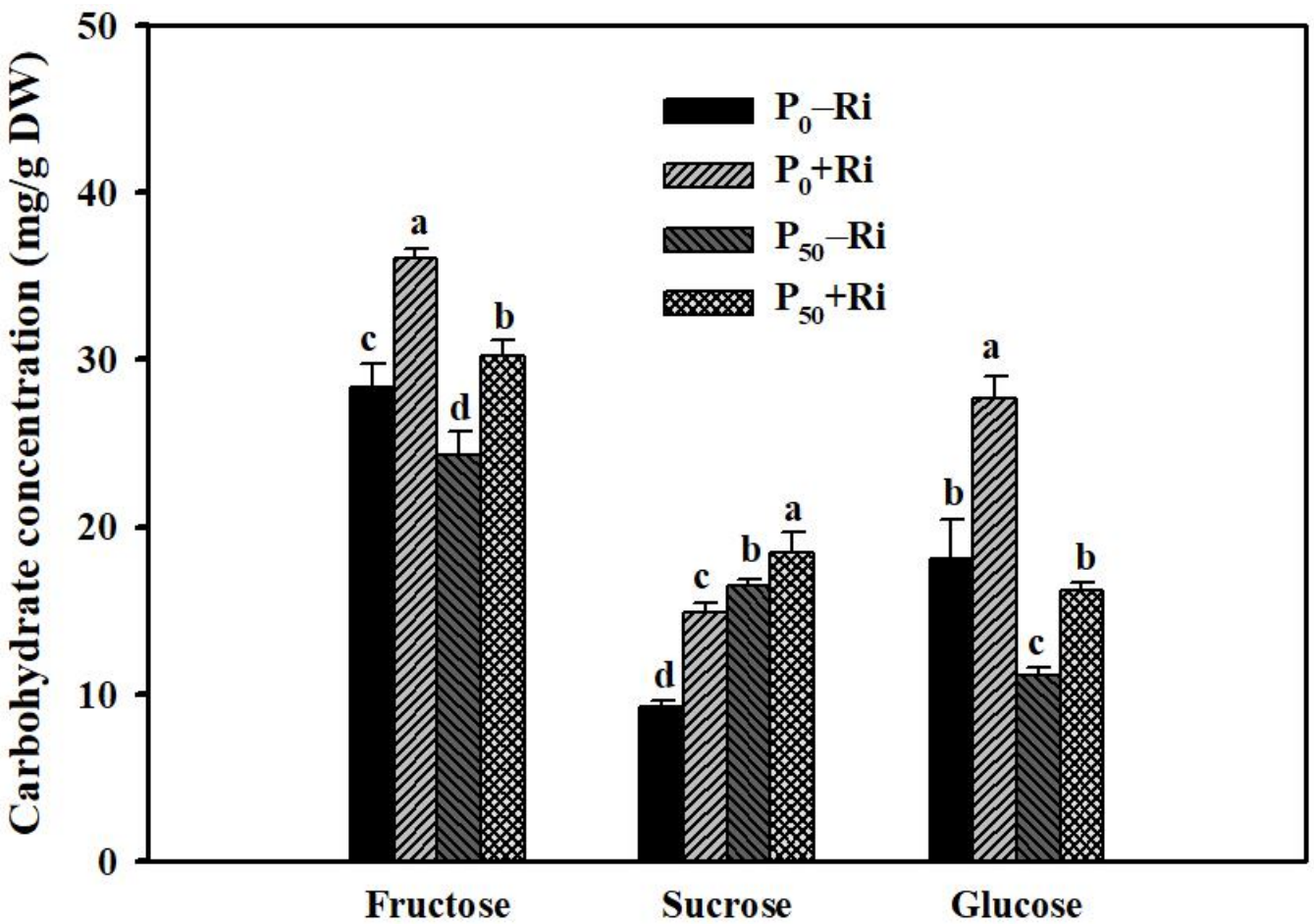

Figure 3. Effects of Rhizophagus intraradices on carbohydrate concentration in roots of lemon (Citrus limon L.) seedlings grown in $0 \mathrm{mg} / \mathrm{kg}\left(\mathrm{P}_{0}\right)$ and $50 \mathrm{mg} / \mathrm{kg}\left(\mathrm{P}_{50}\right) \mathrm{P}$ levels. Data (means $\pm \mathrm{SD}$, $n=6)$ are followed by different letters above the bars, which indicate significant differences between treatments at 0.05 level by LSD.

\subsection{Changes in Relative Expression of Root P-Related Genes}

Compared with $\mathrm{P}_{50}, \mathrm{P}_{0}$ treatment significantly suppressed the expression levels of $C l P T 1, C l P T 3$, and ClPT7, but it dramatically stimulated the expression of ClPT5 in nonAMF seedlings, and $\mathrm{P}$ levels did not affect the expression of these genes in AMF-colonized seedlings (Figure 4a). However, $\mathrm{P}_{0}$ memorably upregulated the expression levels of root acid phosphatase genes CIPAP1 in non-AMF seedlings, ClPAP2 in AMF seedlings, and CIPAP3 in both AMF- and non-AMF seedlings (Figure $4 \mathrm{~b}$ and Table 4 ).

Compared with non-AMF treatment, AMF inoculation substantially upregulated the expression levels of root $\mathrm{P}$ transporter genes $\mathrm{ClPT1}, \mathrm{ClPT3}, \mathrm{ClPT5}$, and $\mathrm{ClPT7}$ by $3.45,1.76$, 11.38 , and 3.65 times under $P_{0}$ and by $1.41,1.37,13.63$, and 1.78 times under $P_{50}$ treatment, respectively. However, mycorrhizal treatment dramatically downregulated the expression of $C l P T 2$ by 3.37 and 3.89 times under $\mathrm{P}_{0}$ and $\mathrm{P}_{50}$, respectively, as compared with non-AMF treatment (Figure 4a). In addition, AMF inoculation only dramatically upregulated the expression levels of CIPAP1, while it notably downregulated the expression levels of CIPAP2 and CIPAP3 (Figure $4 \mathrm{~b}$ and Table 4 ). 

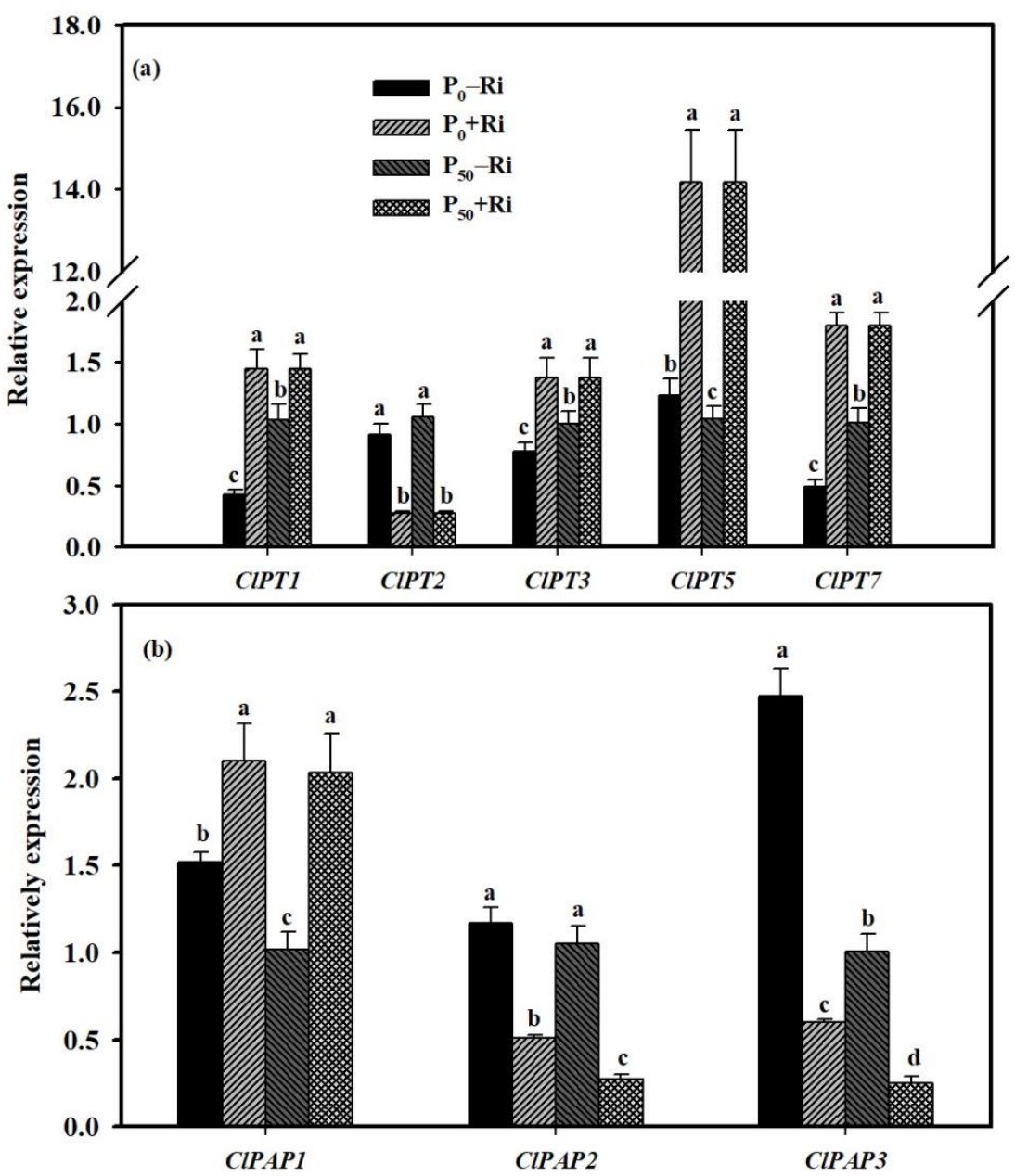

Figure 4. Effects of Rhizophagus intraradices on relative expression of $\mathrm{P}$ transporter genes (a) and acid phosphatase gene $(\mathbf{b})$ in roots of lemon (Citrus limon L.) seedlings grown in $0\left(\mathrm{P}_{0}\right)$ and $50 \mathrm{mg} / \mathrm{kg}\left(\mathrm{P}_{50}\right)$ P levels. Data (means $\pm \mathrm{SD}, n=3$ ) are followed by different letters above the bars, which indicate significant differences between treatments at 0.05 level by LSD.

\subsection{Expression of LR-Related Genes}

Mycorrhizal colonization significantly increased the expression of ClPSK6 by 3.90-fold and 2.22-fold and that of ClRSI-1 by 3.43-fold and 2.21-fold under $\mathrm{P}_{0}$ and $\mathrm{P}_{50}$, respectively (Figure 5). In contrast, the expression of ClKRP 6 was markedly decreased by AMF inoculation under $\mathrm{P}_{50}$ conditions but not affected under $\mathrm{P}_{0}$ conditions. Moreover, in nonAMF seedlings, $\mathrm{P}_{0}$ only suppressed the expression of ClPSK6 and ClKRP6 but not ClRSI-1, whereas in AMF-colonized seedlings, $\mathrm{P}_{0}$ dramatically stimulated the expression of ClRSI-1 and ClKRP6 but did not affect ClPSK6 expression. A significant $(p<0.05)$ interaction between $P$ fertilization treatments and AMF treatments was observed for the expression of ClPSK6, ClKRP6, and ClRSI-1 (Table 4).

\subsection{Principal Component Analysis}

We performed PCA to investigate the correlation between RSA and the main factors (P concentration and transportation, phosphatase activity, sugar content, and LR-related genes). The results show $77.3 \%$ ( $53.7 \%$ and $23.6 \%$ of the first and second axes, respectively) of the total variance (Figure 6). Interestingly, most P transporter genes (except ClPT2) and CIPAP1 and CIRSI-1 negatively correlated with root system traits, which were not affected by AMF inoculation but markedly affected by P deficiency. The RSA traits and LR numbers were positively closely correlated with AMF colonization; the contents of root $\mathrm{P}$ and carbohydrate; phosphatase activity; and the expression levels of ClKRP6, ClPSK6, ClPT2, 
and CIPAP2, which were significantly promoted by AMF inoculation and P deficiency stimulation (Figure 6).

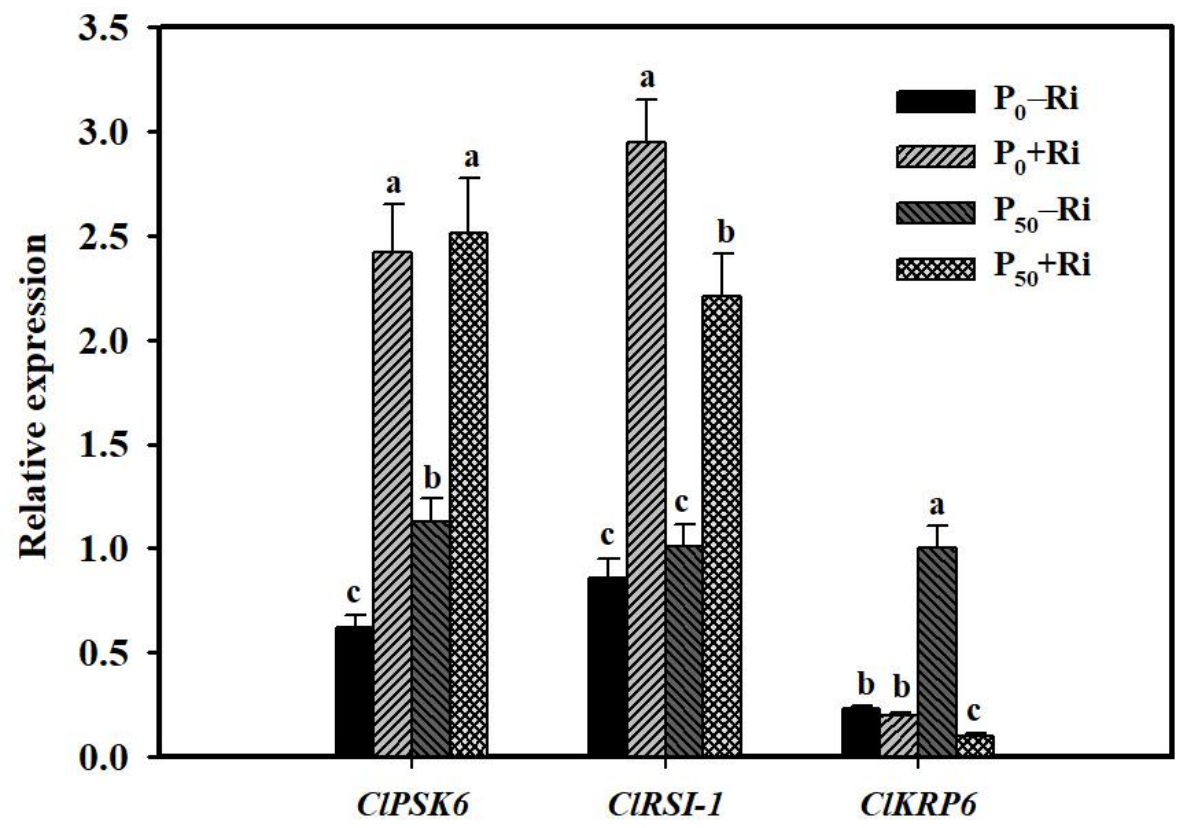

Figure 5. Effects of Rhizophagus intraradices on relative expression of lateral-root-related genes of lemon (Citrus limon L.) seedlings grown in $0\left(\mathrm{P}_{0}\right)$ and $50 \mathrm{mg} / \mathrm{kg}\left(\mathrm{P}_{50}\right) \mathrm{P}$ levels. Data (means $\left.\pm \mathrm{SD}, n=3\right)$ are followed by different letters above the bars, which indicate significant differences between treatments at 0.05 level by LSD.

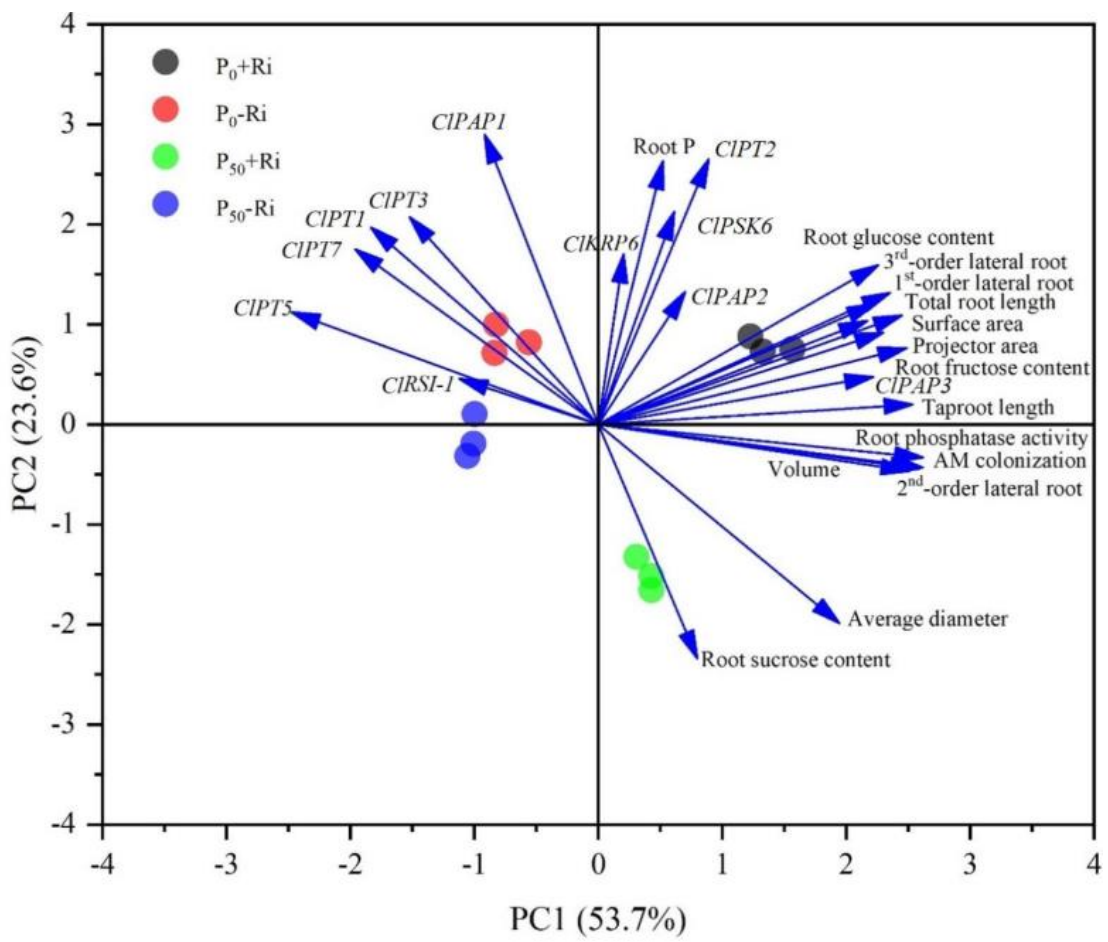

Figure 6. The unsupervised principal component analysis (PCA) of selective physiological parameters in lemon (Citrus limon L.) seedlings inoculated with Rhizophagus intraradices under $\mathrm{P}_{0}$ and $\mathrm{P}_{50}$ conditions. Abbreviation: $\mathrm{P}_{0}: 0 \mathrm{mg} / \mathrm{kg} ; \mathrm{P}_{50}: 50 \mathrm{mg} / \mathrm{kg}$. 


\section{Discussion}

The Citrus genus comprises woody plants with thick roots, including lemons, which are heavily dependent on AMF. The present study shows that lemon seedlings have $68.63 \%$ and $49.10 \%$ mycorrhizal colonization under $\mathrm{P}_{0}$ and $\mathrm{P}_{50}$ conditions, respectively, which is consistent with the results of a previous study on Poncirus trifoliata colonized by Funneliformis mosseae under different P levels [11,21]. These results further confirm the high dependency of citrus species on AMF. Although previous studies have demonstrated the importance of AMF and P in the development of plant RSA, most have focused on its morphology and physiology $[1,11,28]$. Therefore, it is important to clarify the effects of AMF and P levels on RSA and screen out the main factor underlying this dependency when there is an interaction between AMF and P.

The regulation of AMF on the RSA of host plants is mainly manifested in the increase in root length, surface area and projection area, number of LRs, and changes in root hair density. However, the regulation effects depend on the plant and/or fungal species [29]. In the present study, AMF-colonized seedlings showed better RSA characteristics than noncolonized seedlings regardless of substrate P levels, which is in accordance with the results of previous studies on trifoliate orange [28] and strawberry [30] colonized by various AM fungi. Moreover, the effective utilization of $\mathrm{P}$ can promote RSA by increasing the density and length of root hairs and the formation and elongation of LRs [31]. Under low $\mathrm{P}$ treatment, LR numbers and root hair density in Arabidopsis thaliana can be increased through a reduction in taproot length, thus improving the RSA [32]. The present study shows that $\mathrm{P}$ deficiency strongly stimulates root development and increases RSA parameters, which is inconsistent with the research results on tea plants under a low P treatment $(0.5 \mathrm{mM})$ [12]. It is likely that the effect of $\mathrm{P}$ addition and different $\mathrm{P}$ levels on RSA may be related to species specificity, as well as closely related to the environmental conditions of plant growth [33].

It is well known that an improvement in root morphology by AMF is mainly due to its promotion of $\mathrm{P}$ absorption and metabolism by host plants [34,35]. In the present study, AMF inoculation resulted in markedly higher P content and phosphatase activities in roots when compared to non-AMF seedlings, because extracellular mycorrhizal hyphae secreted and accumulated a large amount of phosphatase, which enhances the activity of phosphatase and promotes the absorption of P by host plants [36]. PT genes play a critical role in $\mathrm{P}$ absorption and transportation. The present study shows that AMF induces an intense upregulation in the relative expression of ClPT1, ClPT3, ClPT5, and CIPT7, which is consistent with the findings of Shao et al. [12] on tea plants colonized by Clariodeoglomus etunicatum and the findings of Liu et al. [37] on trifoliate orange colonized by Funneliformis mosseae. Such results indicate that the enhancement in P absorption and transportation by AMF is mainly concentrated in the roots, as mycorrhizal PTs are located around the arbuscule membrane [38].

In addition, acid phosphatase genes (PAPS) mainly act on the strength of phosphatase activity, and these PAPS could be induced under low P stress, thereby enhancing the activity of phosphatase [39]. It has been shown that P deficiency induces PtPAP expression and acid phosphatase activity in trifoliate orange plants [40]. In the present study, AMF inoculation significantly upregulated the expression of CIPAP1 but notably decreased the expression of CIPAP2 and CIPAP3 in lemon seedling roots, which is in accordance with the results of Liu et al. [37], who observed a downregulation trend in trifoliate orange under 0.1 and $1 \mathrm{mM} P$ levels, indicating that the activities of phosphatase enzymes are mainly regulated by CIPAP1 in lemon seedlings colonized by Rhizophagus intraradices. Both PAP2 and PAP3 play significant roles in catalyzing organic $P$ storage in plants, releasing inorganic $P$, and ensuring P supply [41]. Subsequently, AMF colonization induced PAP1 expression and, thus, secreted phosphatase outside the cells to hydrolyze the P source outside the plant for further utilization [42]. Interestingly, PCA showed that the PT genes, including ClPT1, ClPT3, CIPT5, and CIPT7, and the phosphatase gene ClPAP1, were negatively correlated with RSA parameters, but root $\mathrm{P}$ content was significantly positively correlated with RSA characteristics, suggesting that CIPTs and CIPAP1 did not directly participate in the 
establishment of root configuration but played a role in $\mathrm{P}$ absorption and transport, which was related to root configuration through the increase in root $\mathrm{P}$.

Studies on trifoliate orange showed that colonization by F. mosseae significantly increased plant sucrose, fructose, and glucose concentrations under 0,3 , and $30 \mathrm{mM} \mathrm{P}$ treatment [21], and the same results were obtained by Wu et al. [43] on trifoliate orange colonized by F. mosseae and Paraglomus occultum under drought stress. The present study shows a significantly higher concentration in carbohydrate under two P levels, which is consistent with the above studies. Nevertheless, the combined effect of P and AMF weakened the sugar accumulation in lemon roots, especially sucrose content, which may be due to the consumption of mycorrhizal fungi, as about $4-20 \%$ of the host carbohydrates (mainly glucose) would provide for AMF growth [44]. Moreover, exogenous fructose, glucose, and sucrose application improved the root development and increased root system traits in trifoliate orange seedlings [44]. Zhou et al. [45] also demonstrated that sugar signaling mediated the cluster root formation induced by $\mathrm{P}$ starvation in white lupin. The PCA showed a positive correlation between RSA traits (including LR development) and the contents of sucrose, glucose, and fructose. However, Chen et al. [35] proposed that sugar metabolism had dramatically negative effects on LR development. In fact, carbohydrate competition occurred between AMF and root development [35]. Root carbohydrates may contribute to the metabolism necessary for RSA on the premise of meeting the growth needs of AMF. The relationship between sugar metabolism and the establishment of RSA is complex and requires further detailed research.

Molecular indicators are particularly important for the establishment of RSA. Previous studies have shown that ARFs and KPR1 are involved in LR development in Arabidopsis [18,19]. Chen et al. [1] reported that the expression of KRP6, PSK6, and RSI-1 was involved in the LR development of trifoliate orange colonized by R. irregularis, in which PSK6 was identified as the key gene in LR indication. In addition, auxin synthesis and transportrelated genes and expansions have been widely implicated in the growth and development of roots and root hairs in several plant species $[1,11,46]$. In the present study, P deficiency significantly inhibited the expression of ClPSK6 and ClKRP6 in non-AMF seedlings. AMF inoculation sustainably upregulated CIPSK6 and CIRSI-1 expression in lemon seedlings under both $\mathrm{P}_{0}$ and $\mathrm{P}_{50}$ conditions, as well as ClKPR6 expression under $\mathrm{P}_{0}$ conditions. These results are consistent with those of Chen et al. [1] on trifoliate orange colonized by $R$. irregularis. Additionally, the PCA showed that the expression of ClKRP6 and ClPSK6 was closely positively correlated with RSA traits and AMF colonization, which is in accordance with the data showing that an increased expression of CIPSK6 and ClKRP6 promotes LR formation [1,47]. Nevertheless, our results show that the expression of ClRSI-1 is negatively correlated with RSA parameters, suggesting that an increased expression of CIRSI-1 suppresses RSA formation. The responses of gene expression patterns induced by AMF species are likely dependent on plant genotypes, which will be addressed.

\section{Conclusions}

AMF promoted root $\mathrm{P}$ accumulation in lemon seedlings by upregulating the expression of CIPTs and CIPAP1, along with an improvement in RSA by promoting the accumulation and distribution of root carbohydrates. Furthermore, AMF upregulated the expression of LR-related genes, thus contributing to LR formation and RSA improvement. Overall, compared to $\mathrm{P}$ levels, AMF had a greater impact on the studied parameters, at least within the range of $\mathrm{P}$ levels tested in the present study (Figure 7 ). Therefore, in the future management of citrus orchards, more attention should be paid to the number of soil and root AMF populations, such as sod cultivation in the orchard to promote the formation of AMF populations and their colonization in roots, which will facilitate the establishment of RSA and, thus, promote the vigorous growth of citrus trees. 


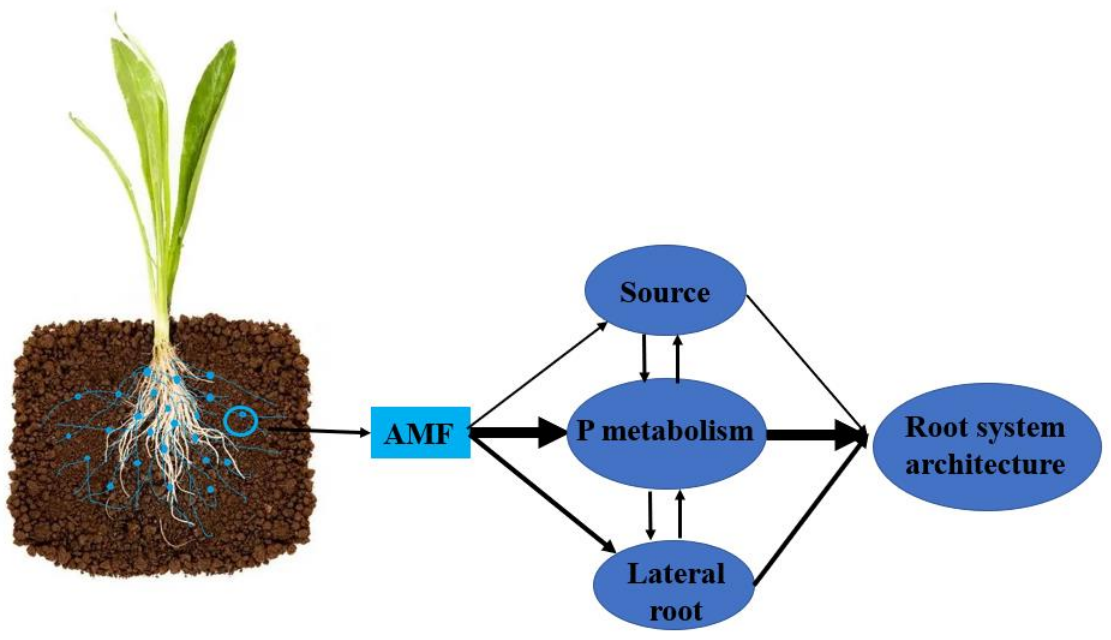

Figure 7. Construction diagram of AMF acting on root system in lemon (Citrus limon L.) seedlings. The thickness of the arrow line indicates the strength of its functions.

Author Contributions: Conceptualization, C.-Y.L. and Q.-S.W.; methodology, C.-Y.L., Q.-S.W., X.-N.G., X.-L.W. and F.-J.D.; data curation and statistical analysis, C.-Y.L., X.-N.G., X.-L.W., F.-J.D. and Q.-S.W.; writing —original draft preparation, C.-Y.L.; writing—review and editing, C.-Y.L. and Q.-S.W.; supervision, Q.-S.W. All authors have read and agreed to the published version of the manuscript.

Funding: The authors would like to extend their sincere appreciation to the National Natural Science Foundation of China (No. 32102315) and the Science-Technology Research Project of Hubei Provincial Department of Education, China (Q20191306).

Institutional Review Board Statement: Not applicable.

Informed Consent Statement: Not applicable.

Data Availability Statement: All the data supporting the findings of this study are included in this article.

Acknowledgments: This work was supported by the National Natural Science Foundation of China (No. 32102315) and the Science-Technology Research Project of Hubei Provincial Department of Education, China (Q20191306).

Conflicts of Interest: The authors declare no conflict of interest.

\section{References}

1. Chen, W.-L.; Li, J.; Zhu, H.-H.; Xu, P.-Y.; Chen, J.-Z.; Yao, Q. The differential and interactive effects of arbuscular mycorrhizal fungus and phosphorus on the lateral root formation in Poncirus trifoliata (L.). Sci. Horti. 2017, 217, 258-265. [CrossRef]

2. Flavel, R.-J.; Guppy, C.-N.; Tighe, M.-K.; Watt, M.; Young, I.-M. Quantifying the response of wheat (Triticum aestivum L.) root system architecture to phosphorus in an Oxisol. Plant Soil 2014, 385, 303-310. [CrossRef]

3. Funakoshi, Y.; Daimon, H.; Matsumura, A. Morphological and physiological studies on densely branched lateral roots triggered by localized phosphate in Sesbania cannabina. J. Plant Nutr. Soil Sci. 2018, 181, 336-344. [CrossRef]

4. Abel, S. Phosphate scouting by root tips. Curr. Opin. Plant Biol. 2017, 39, 168-177. [CrossRef]

5. Johnston, A.-E.; Poulton, P.-R.; Fixen, P.-E.; Curtin, D. Phosphorus: Its efficient use in agriculture. In Advances in Agronomy; Sparks, D.L., Ed.; Academic Press: San Diego, CA, USA, 2014; pp. 177-228. [CrossRef]

6. Ros, M.-B.-H.; de Deyn, G.-B.; Koopmans, G.-F.; Oenema, O.; van Groenigen, J.-W. What root traits determine grass resistance to phosphorus deficiency in production grassland? J. Plant Nutr. Soil Sci. 2018, 181, 323-335. [CrossRef]

7. Wissuwa, M.; Gonzalez, D.; Watts-Williams, S.-J. The contribution of plant traits and soil microbes to phosphorus uptake from low-phosphorus soil in upland rice varieties. Plant Soil 2020, 448, 523-537. [CrossRef]

8. Ma, X.-M.; Li, X.-L.; Ludewig, U. Arbuscular mycorrhizal colonisation outcompetes root hairs in maize under low phosphorus availability. Ann. Bot. 2020, 127, 155-166. [CrossRef]

9. Liu, C.-Y.; Wu, Q.-S. Responses of plant growth, root morphology, chlorophyll and indoleacetic acid to phosphorus stress in trifoliate orange. Biotechnology 2017, 16, 40-44. [CrossRef]

10. Habibzadeh, Y. The effects of arbuscular mycorrhizal fungi and phosphorus levels on dry matter production and root traits in cucumber (Cucumis sativus L.). Afr. J. Environ. Sci. Technol. 2015, 9, 65-70. [CrossRef] 
11. Liu, C.-Y.; Wang, P.; Zhang, D.-J.; Zou, Y.-N.; Kuča, K.; Wu, Q.S. Mycorrhiza-induced change in root hair growth is associated with IAA accumulation and expression of EXPS in trifoliate orange under two P levels. Sci. Horti. 2018, 234, 227-235. [CrossRef]

12. Shao, Y.-D.; Hu, X.-C.; Wu, Q.-S.; Yang, T.-Y.; Srivastava, A.-K.; Zhang, D.-J.; Gao, X.-B.; Kuča, K. Mycorrhizas promote P acquisition of tea plants through changes in root morphology and P transporter gene expression. S. Afr. Bot. 2021, 137, 455-462. [CrossRef]

13. Gutjahr, C.; Casieri, L.; Paszkowski, U. Glomus intraradices induces changes in root system architecture of rice independently of common symbiosis signaling. New Phytol. 2009, 182, 829-837. [CrossRef] [PubMed]

14. Tian, H.; De Smet, I.; Ding, Z. Shaping a root system: Regulating lateral versus primary root growth. Trends Plant Sci. 2014, 19, 426-431. [CrossRef] [PubMed]

15. Zheng, F.-L.; Liang, S.-M.; Chu, X.-N.; Yang, Y.-L.; Wu, Q.-S. Mycorrhizal fungi enhance flooding tolerance of peach through inducing proline accumulation and improving root architecture. Plant Soil Environ. 2020, 66, 624-631. [CrossRef]

16. Cozzolino, V.; Pigna, M.; Di Meo, V.; Caporale, A.-G.; Violante, A. Effects of arbuscular mycorrhizal inoculation and phosphorus supply on the growth of Lactuca sativa L. and arsenic and phosphorus availability in an arsenic polluted soil under non-sterile conditions. Appl. Soil Ecol. 2010, 45, 262-268. [CrossRef]

17. Xie, X.-Y.; Weng, B.-S.; Cai, B.-P.; Dong, Y.-R.; Yan, C.-L. Effects of arbuscular mycorrhizal inoculation and phosphorus supply on the growth and nutrient uptake of Kandelia obovata (Sheue, Liu \& Yong) seedlings in autoclaved soil. Appl. Soil Ecol. 2014, 75, 162-171. [CrossRef]

18. Okushima, Y.; Fukaki, H.; Onoda, M.; Theologis, A.; Tasaka, M. ARF7 and ARF19 regulate lateral root formation via direct activation of LBD/ASL genes in Arabidopsis. Plant Cell 2007, 19, 118-130. [CrossRef]

19. Ren, H.; Santner, A.; Pozo, J.-C.-D.; Murray, J.-A.; Estelle, M. Degradation of the cyclin-dependent kinase inhibitor KRP1 is regulated by two different ubiquitin E3 ligases. Plant J. 2008, 53, 705-716. [CrossRef]

20. Zhang, Y.; Anja, P.; Caroline, M.; Liu, S.; Tai, H.; Josefine, N.; Yeh, C.-T.; Nina, O.; Christa, L.; Schnable, P.-S. The Aux/IAA gene rum1 involved in seminal and lateral root formation controls vascular patterning in maize (Zea mays L.) primary roots. J. Exp. Bot. 2015, 65, 4919-4930. [CrossRef]

21. Wu, Q.-S.; Srivastava, A.-K.; Li, Y. Effects of mycorrhizal symbiosis on growth behavior and carbohydrate metabolism of trifoliate orange under different substrate P levels. J. Plant Growth Regul. 2015, 34, 499-508. [CrossRef]

22. Wu, Q.-S.; Liu, C.-Y.; Zhang, D.-J.; Zou, Y.-N.; He, X.-H.; Wu, Q.-H. Mycorrhiza alters the profile of root hairs in trifoliate orange Mycorrhiza 2016, 26, 237-247. [CrossRef] [PubMed]

23. Liu, C.-Y.; Zhang, F.; Zhang, D.-J.; Zou, Y.-N.; Shu, B.; Wu, Q.-S. Transcriptome analysis reveals improved root hair growth in trifoliate orange seedlings by arbuscular mycorrhizal fungi. Plant Growth Regul. 2020, 95, 195-203. [CrossRef]

24. Phillips, J.-M.; Hayman, D.-S. Improved procedures for clearing roots and staining parasitic and vesicular-arbuscular mycorrhizal fungi for rapid assessment of infection. Trans Br. Mycol. Soc. 1970, 55, 158-161. [CrossRef]

25. Mc Lachlan, K.-D.; Elliot, D.-E.; De Marco, D.-G.; Garran, J.-H. Leaf acid phosphatase isozymes in the diagnosis of phosphorus status in field-grown wheat. Aust. J. Agric. Res. 1987, 38, 1-13. [CrossRef]

26. Yan, J.-W.; Yuan, F.-R.; Long, G.-Y.; Qin, L.; Deng, Z.-N. Selection of reference genes for quantitative real-time RT-PCR analysis in citrus. Mol. Biol. Rep. 2012, 39, 1831-1838. [CrossRef] [PubMed]

27. Livak, K.-J.; Schmittgen, T.-D. Analysis of relative gene expression data using real-time quantitative PCR and the $2^{-\Delta \Delta C t}$ method. Methods 2001, 25, 402-408. [CrossRef]

28. Liu, C.-Y.; Srivastava, A.-K.; Wu, Q.-S. Mycorrhizal fungi regulate root responses and leaf physiological activities in trifoliate orange. Not. Bot. Horti Agrobot. 2017, 45, 17-21. [CrossRef]

29. Wang, X.; Pan, Q.; Chen, F.; Yan, X.; Liao, H. Effects of co-inoculation with arbuscular mycorrhizal fungi and rhizobia on soybean growth as related to root architecture and availability of N and P. Mycorrhiza 2010, 21, 173-181. [CrossRef]

30. Norman, J.-R.; Atkinson, D.; Hooker, J.-E. Arbuscular mycorrhizal fungal-induced alteration to root architecture in strawberry and induced resistance to the root pathogen Phytophthora fragariae. Plant Soil 1996, 185, 191-198. [CrossRef]

31. López-Bucio, J.; Hernández-Abreu, E.; Sánchez-Calderón, L.; Nieto-Jacobo, M.-F.; Simpson, J.; Herrera-Estrella, L. Phosphate availability alters architecture and causes changes in hormone sensitivity in the Arabidopsis root system. Plant Physiol. 2002, 129, 244-256. [CrossRef]

32. Gahoonia, T.-S.; Nielsen, N.-E. Phosphorus (P) uptake and growth of a root hairless barley mutant (bald root barley, brb) and wild type in low- and high-P soils. Plant Cell Environ. 2003, 26, 1759-1766. [CrossRef]

33. Vysotskaya, L.-B.; Trekozova, A.-W.; Kudoyarova, G.-R. Effect of phosphorus starvation on hormone content and growth of barley plants. Acta Physiol. Plant. 2016, 38, 1-6. [CrossRef]

34. Zhang, C.; Simpson, R.-J.; Kim, C.-M.; Warthmann, N.; Delhaize, E.; Dolan, L.; Byrne, M.-E.; Wu, Y.; Ryan, P.-R. Do longer root hairs improve phosphorus uptake? Testing the hypothesis with transgenic Brachypodium distachyon lines overexpressing endogenous RSL genes. New Phytol. 2018, 217, 1654-1666. [CrossRef] [PubMed]

35. Chen, W.; Li, J.; Zhu, H.-H.; Xu, P.-Y.; Chen, J.-X.; Yao, Q. Arbuscular mycorrhizal fungus enhances lateral root formation in Poncirus trifoliata (L.) as revealed by RNA-Seq analysis. Front. Plant Sci. 2017, 8, 2039. [CrossRef] [PubMed]

36. Javot, H.; Pumplin, N.; Harrison, M.-J. Phosphate in the arbuscular mycorrhizal symbiosis: Transport properties and regulatory roles. Plant Cell Environ. 2007, 30, 310-322. [CrossRef] [PubMed] 
37. Liu, C.-Y.; Wu, Q.-S.; Zou, Y.-N. Effects of arbuscular mycorrhizal fungi on phosphorous uptake and phosphatase release in trifoliate orange seedlings. Mycosystema 2017, 36, 942-949. [CrossRef]

38. Pumplin, N.; Harrison, M.-J. Live-cell imaging reveals peri arbuscular membrane domains and organelle location in Medicago truncatula roots during arbuscular mycorrhizal symbiosis. Plant Physiol. 2009, 151, 809-819. [CrossRef]

39. Li, C.-C.; Gui, S.-H.; Yang, T.; Walk, T.; Wang, X.-R.; Liao, H. Identification of soybean purple acid phosphatase genes and their expression responses to phosphorus availability and symbiosis. Ann. Bot. 2012, 109, 275-285. [CrossRef]

40. Shu, B.; Wang, P.; Xia, R.-X. Effects of mycorrhizal fungi on phytate phosphorus utilization in trifoliate orange (Poncirus trifoliata L. Raf) seedlings. Acta Physiol. Plant 2014, 36, 1023-1032. [CrossRef]

41. Veneklaas, E.-J.; Lambers, H.; Bragg, J.; Finnegan, P.-M.; Lovelock, C.-E.; Plaxton, W.-C.; Price, C.-A.; Scheible, W.-R.; Shane, M.-W.; White, P.-J.; et al. Opportunities for improving phosphorus-use efficiency in crop plants. New Phytol. 2012, 195, 306-320. [CrossRef]

42. Wasaki, J.; Yamamura, T.; Shinano, T.; Osaki, M. Secreted acid phosphatase is expressed in cluster roots of lupin in response to phosphorus deficiency. Plant Soil 2003, 248, 129-136. [CrossRef]

43. Wu, H.-H.; Zou, Y.-N.; Rahman, M.-M.; Ni, Q.-D.; Wu, Q.-S. Mycorrhizas alter sucrose and proline metabolism in trifoliate orange exposed to drought stress. Sci. Rep. 2017, 7, 42389. [CrossRef] [PubMed]

44. Tian, L.; Li, Y.; Wu, Q.-S. Exogenous carbon magnifies mycorrhizal effects on growth behaviour and sucrose metabolism in trifoliate orange. Not. Bot. Horti Agrobot. 2018, 46, 365. [CrossRef]

45. Zhou, K.-Q.; Yamagishi, M.; Osaki, M.; Masuda, K. Sugar signaling mediates cluster root formation and phosphorus starvationinduced gene expression in white lupin. J. Exp. Bot. 2008, 59, 2749-2756. [CrossRef] [PubMed]

46. Mohanty, S.-K.; Arthikala, M.-K.; Nanjareddy, K.; Lara, M. Plant-symbiont interactions: The functional role of expansins. Symbiosis 2017, 74, 1-10. [CrossRef]

47. Mackowska, K.; Jarosz, A.; Grzebelus, E. Plant regeneration from leaf-derived protoplasts within the Daucus genus: Effect of different conditions in alginate embedding and phytosulfokine application. Plant Cell Tiss. Org. 2014, 117, 241-252. [CrossRef] 